\title{
Financial Literacy and Its Impact on Financial Management of MSMEs in Rembang Regency
}

\author{
Wulan Suryandani ${ }^{1 *}$, Dian Anita Sari ${ }^{2}$ \\ \{wulansuryandani@gmail.com $\left.{ }^{1}\right\}$ \\ Department of Management, STIE YPPI Rembang, Indonesia ${ }^{1,2}$
}

\begin{abstract}
The goal of this study was to see how financial literacy affected financial management at a small business in Rembang Regency. The object of this study are MSMEs that scattered in Rembang Regency. The sampling technique used was purposive sampling. The sample that are using in this research are 101 MSMEs in Rembang Regency. The influence of each variable is determined using binary logistic regression analysis in this study. The findings of this study show that financial literacy has little impact on MSMEs' financial management in Rembang Regency.
\end{abstract}

Keywords: Financial literacy, financial management, MSMEs

\section{Introduction}

In recent years, industrialized and emerging economies have become more concerned about their citizens' level of financial literacy [1]. Financial literacy is defined as the capacity and confidence of an individual to use his or her financial knowledge to make financial decisions [2]. It also involves the ability and confidence of an individual to understand and utilize personal finance related information. Financial literacy is a basic requirement for everyone who wants to avoid financial troubles and challenges. Financial literacy has an impact on the ability to make sound financial decisions, as well as household well-being and business sustainability, according to [3]. Financial literacy is seen as a critical tool for MSMEs' success since it enables them to comprehend and evaluate data to make every day financial decisions in day-to-day operations [4]. Lusardi [5] defines financial literacy as a collection of desirable attitudes, behaviors, and external enabling factors that combine knowledge and cognitive skills with a set of ideal attitudes, behaviors, and external enabling factors. Budgeting, bill paying, debt accumulation and repayment, consumer problem management, and comparison shopping are examples of these skills [6].

Financial literacy has an influence on financial management behavior [7]. Financial management includes personal management, family management, and corporate financial management. Business financial management is very important for every business owner that can be applied in good business management as to facilitate the company' activities [8]. According to [9] there is no conclusive evidence that financial literacy as to effect on changing financial management behavior.

MSME widely acknowledged that have an important role in economic development [10]. MSMEs are even considered to be more resilient to crisis than a large-scale company [11]. One of the factors that hinder the development of MSMEs in Indonesia is the lack of knowledge and ability to manage finance, in addition of that case the level of participation of MSMEs in 
financial institutions is very low, within only $30 \%$ being able to access financing because of the lack of knowledge and understanding of MSMEs in the financial sector [12]. According to the research, the majority of MSMEs' owners in South Africa do not engage in formal financial planning, budgeting, or control, and only retain a few books of account. [3]. Based on [13] MSMEs in Depok have a low level of financial literacy so that it affects business owners in managing business finances with the limited ability that is only recording but has not done a good documentation for financial income and expenditure.

This study aims to investigate the impact of financial literacy on financial management of MSME in Rembang Regency with 5 indicators based on research [14]. The distinction between this study and other research is that this one seeks to determine the impact of financial literacy on financial management, despite the fact that many MSMEs have found that financial literacy has little impact on financial management. Several studies have discovered that financial literacy has an impact on financial management. Financial literacy has an impact on financial management, as evidenced by studies [3], [13], and [9].

\section{Method}

The population of this research is the MSMEs that scattered in Rembang Regency. Respondent that are used on this research are 101 MSMEs that are involved in the group of Forum UMKM Rembang. Method of collecting data by using online questioner. Sampling technique that are used in this research is purposive sampling, with criteria are as follows:

- Member of Forum UMKM Rembang;

- MSMEs must have been running for more than 1 year.

- Sales more than 5 million per month.

- Employees are more than 3 people.

The research variable is financial management as dependent variable and financial literacy as independent variable with 5 dimensions of financial literacy. The dimensions that are using in this research are based on previous research from [14]. are as follows: 1) Basic financial knowledge are a basic knowledge about process that is intended to manage finance effectively and efficiently 2) Saving is a process that assists in placing a person's surplus funds with the aim of easy access to liquidity, financial planning and security; 3) Loan/debt is knowledge and ability to make a simple decisions regarding debt contracts ; 4) Insurance is the ability to measure risk and ways to deal with these risks; and 5) Investment is a process that assists in the formulation of policies and objectives as well as supervision in investment for profit.

The research data were analyzed with descriptive and quantitative analysis. Quantitative analysis is used to analyzed whether the understanding of basic financial knowledge, savings, loan, insurance and investment will affect the financial management of the respondent. The data analysis techniques using binary logistic regression test because this research is about perception. This research is measured using a nominal scale. Nominal scale distinguishes as YES and NO answer, the answer YES is given a value of 1 . YES answer indicate that the financial literacy of the respondent is high. NO answer is given a value of 0 and indicate that the level of financial literacy of the respondent is low. For financial management variable has the same value as financial literacy. The answer of respondent is YES or NO. YES answer means that financial management of respondent is high and NO answer means that financial management of respondent is low. 
Binary logistic regression is used to test the hypothesis in this study because the dependent variable is categorical variable with has two categories (dummy variable) so that it cannot be solved using multiple regression [15]. States that logistic regression ignores heteroscedastic, meaning that the dependent variable does not require homoscedastic for each of the independent variables. Logistic regression in this study is used to test the understanding of finance, loans, savings, insurance, investment that will affect financial management among MSMEs in Rembang Regency. The test was carried out at a significant level $(\alpha) 5 \%(0,05)$.

\section{Results and Discussions}

\subsection{Results}

\subsubsection{Instrument testing}

The purpose of the instrument testing in this study was to assess the statement items' reliability and validity. Instrumental exam of 30 respondents utilizing 21 statements linked to financial literacy and financial management. The following are the test results:

\subsubsection{Reliability test}

The purpose of this reliability test was to determine the research instruments' reliability so that each item of the questionnaire could be trusted. The Cronbach Alpha of 0.702 indicates that the variables in this study are moderately reliable, according to the reliability test results.

\subsubsection{Validity test}

The statement item is valid with a significant level of 0,05 percent in the validity test [16], where an instrument is said to be valid if it is computed with the formula degree of freedom (df) $=\mathrm{n}-2$, where $\mathrm{n}$ is the number of samples, and the value is positive. Based on the findings of the validity test, which included 30 samples, all of the forming items have a correlation of 0.25 . As a result, it can be determined that all of the items are correct.

\subsubsection{Data analysis}

The respondent's degree of financial literacy may be described using the findings of the analysis produced for each of the variables employed, starting with fundamental financial knowledge, saving, loan, insurance, and investment, as shown in Table 1.

Table 1. Financial Literacy Level of MSMEs in Rembang Regency

\begin{tabular}{lllll}
\hline Financial Literacy Indicators & \multicolumn{4}{c}{ Financial Literacy Presentation } \\
& No & Yes & Low & High \\
\hline Basic financial knowledge & 6 & 95 & $6 \%$ & $94 \%$ \\
Saving & 1 & 100 & $1 \%$ & $99 \%$ \\
Loan & 4 & 97 & $4 \%$ & $96 \%$ \\
Insurance & 26 & 75 & $25 \%$ & $75 \%$ \\
Investment & 6 & 95 & $6 \%$ & $94 \%$ \\
\hline
\end{tabular}


From the Table 1 above, it can be seen that the respondents have a higher understanding of basic financial knowledge by $94 \%$, saving $99 \%$, loan $96 \%$, insurance $75 \%$ and investment $94 \%$. The survey also shows that respondents have a high understanding of savings at $99 \%$ it means that the owner of MSMEs in Rembang Regency knows very well about saving in financial aspect. The lowest understanding at insurance by $75 \%$ it means that the owner of MSMEs in Rembang Regency have less understanding about insurance, the meaning of insurance, insurance product and the benefit of insurance. Table 1 also shows that understanding of loan, insurance and investment is also high because is more than $60 \%$. This means that in general the understanding of financial literacy at MSMEs in Rembang is high.

The effect of independent factors on dependent variables will be tested in this Fit Model test show in Table 2, where the independent variable is financial literacy $(\mathrm{x})$ and the dependent variable is financial management (y). The initial step in the process is to test the complete model (overall model fit). This test compares the initial (intercept alone) value of -2 log likelihood ($2 \mathrm{LL}$ ) with the final model's value of $-2 \log$ likelihood (-2LL). The decrease in the value between the initial -2LL (intercept only) and the final $-2 \log$ likelihood (-2LL) suggests that the model fits the data.

Table 2. Model Fit Test

\begin{tabular}{lllll}
\hline Iteration & \multirow{2}{*}{-2 Log likelihood } & $\begin{array}{l}\text { Coefficients } \\
\text { Constant }\end{array}$ & Kat_A \\
\hline Step 1 & 1 & 134.640 & -1.429 & 1.173 \\
& 2 & 134.519 & -1.752 & 1.495 \\
& 3 & 134.517 & -1.791 & 1.534 \\
& 4 & 134.517 & -1.792 & 1.535 \\
\hline
\end{tabular}

Based on Table 2 shows the comparison between the values of -2LL in the intercept only model and -2LL in the final model. From the table it is known that the initial -2LL number (intercept only) which only includes constants is 134.640 and at the final -2LL, the -2LL number has decreased to 134.517 . This shows that the hypothesized model is fit with the data.

\subsection{Ordinal logistic regression testing results}

Ordinal logistic regression testing was carried out to see the variables that affect financial management. Following are the results of the ordinal logistic regression on Table 3.

Table 3. Ordinal Logistic Regression Test

\begin{tabular}{llllllllll}
\hline \multicolumn{10}{c}{ Variables in the Equation } \\
& & \multirow{2}{*}{ B } & S.E. & Wald & df & Sig. & $\operatorname{Exp}(\mathbf{B})$ & \multicolumn{2}{c}{$\mathbf{9 5 \%}$ C.I.for EXP(B) } \\
\hline Step & Kat_A & 1.535 & 1.100 & 1.948 & 1 & .163 & 4.642 & .537 & 40.082 \\
$1^{\text {a }}$ & Constant & -1.792 & 1.080 & 2.752 & 1 & .097 & .167 & & \\
\hline
\end{tabular}

Based on the results of the ordinal logistic regression test, it is known that the independent variable has no effect on the financial management of MSMEs. The significance threshold for this test is 0,163 , according to the results. Financial literacy has little effect on financial management, it can be concluded. Based on table 3 , the following equation is obtained: 


$$
\log [\mathrm{P} /(1-\mathrm{P})]=-1,792+1,535+1,110
$$

\subsection{Discussion}

This research is a study on the level of financial literacy among MSMEs in Rembang Regency. Literacy level measurement activities contain information about the understanding of financial literacy that will affect financial management. The components contained in financial literacy are general knowledge of finance, banking, insurance, and investment. Through these components, an indicator that shows the position, the condition of actual financial knowledge of MSME owners in Rembang Regency can be obtained. The results of the tests that have been carried out show that the financial literacy variable has a regression coefficient of 1.535 with a significance value of 0.163 which means it has no influence on financial management The results of this study are different from [13] study which states that the level of financial literacy affects the financial management of MSMEs.

In the meantime, [8] state that financial literacy has an influence on MSMEs when doing a financial management, besides that [8] also stated that MSMEs needs to understand and apply financial literacy to do a financial management for their business.

The findings of this study show that having a high level of financial literacy has little bearing on financial management. This is also supported by the findings of a study by [17], which found that financial literacy has no effect on financial management because financial attitude has a greater impact on financial management. As a result, financial literacy becomes a supporting part of financial attitude, and financial attitudes become the main controller or the last gate of decision, even if a person truly understands all aspects of finance.

\section{Conclusion}

Based on the results of the study, it was found that financial literacy had no influence on financial management at MSMEs in Rembang Regency. Although it was found that the level of financial literacy at MSMEs in Rembang Regency was high, it did not affect financial management. This can happen because financial management is not only influenced by financial literacy. Based on the results found by [17] it is stated that there are other factors that affect financial management such as financial attitude. Basically, financial attitude is the main control in making decisions related to finance. So even though financial literacy is high and knows many things related to finance, that knowledge is not carried out so that it will not have an impact on financial management.

This study also has many limitations. The limitation of this research is that the research sample is limited only to MSMEs which are members of the Rembang UMKM Forum group. So for further research, it can increase the number of research samples. In addition, the only variable used in this study is financial literacy, for further research it may be possible to add other variables such as financial attitudes, financial inclusion and financial behavior as variables because financial management has many influencing factors besides financial literacy. 


\section{Acknowledgement}

This research is fully supported by Sekolah Tinggi Ilmu Ekonomi YPPI Rembang, Indonesia.

\section{References}

[1] PISA, "Financial Literacy Assessment Framework," no. April, pp. 1-39, 2012.

[2] S. J. Huston, "Measuring Financial Literacy," J. Consum. Aff., vol. 44, no. 2, pp. 296-316, 2010.

[3] O. Fatoki, "The Financial Literacy of Micro Entrepreneurs in South Africa," J. Soc. Sci., vol. 40, no. 2, pp. 151-158, 2014.

[4] W. Suryandari and H. Muniroh, "Literasi Keuangan Dan Pengaruhnya Terhadap Kinerja Umkm Batik Tulis Lasem,” Fokus Ekon. J. Ilm. Ekon., vol. 15, no. 1, pp. 65-77, 2020.

[5] L. Klapper and A. Lusardi, "Financial literacy and financial resilience: Evidence from around the world," Financ. Manag., vol. 49, no. 3, pp. 589-614, 2020.

[6] C. M. Reich and J. S. Berman, "Do Financial Literacy Classes Help? An Experimental Assessment in a Low-Income Population,” J. Soc. Serv. Res., vol. 41, no. 2, pp. 193-203, 2015.

[7] M. Ameliawati and R. Setiyani, "The Influence of Financial Attitude, Financial Socialization, and Financial Experience to Financial Management Behavior with Financial Literacy as the Mediation Variable," KnE Soc. Sci., vol. 3, no. 10, p. 811, 2018.

[8] A. Kasim and M. Ahmad, "EFFECT OF SOCIAL ECONOMIC CHARACTERISTICS ON FINANCIAL LITERACY AND FINANCIAL MANAGEMENT OF SMALL AND," vol. 4, no. 08, pp. 13-28, 2020.

[9] M. Kebede, N. jit D. Kaur, and J. Kuar, "Financial literacy and management of personal finance: A review of recent literatures," Res. J. Financ. Account., vol. 6, no. 13, pp. 92-107, 2015.

[10] H. Bloch and M. Bhattacharya, "Promotion of Innovation and Job Growth in Small- and MediumSized Enterprises in Australia: Evidence and Policy Issues," Aust. Econ. Rev., vol. 49, no. 2, pp. 192-199, 2016.

[11] T. T. H. Tambunan, "The impact of the economic crisis on micro, small, and medium enterprises and their crisis mitigation measures in Southeast Asia with reference to Indonesia," Asia Pacific Policy Stud., vol. 6, no. 1, pp. 19-39, 2019.

[12] M. H. Yuneline, "Financial Literacy and i ts Impact on Funding Source' s Decision -Making," vol. 6, no. 1, pp. 1-10, 2020.

[13] B. D. Anggraeni, "Pengaruh Tingkat Literasi Keuangan Pemilik Usaha Terhadap Pengeloaan Keuangan. Studi Kasus : Umkm Depok," J. Vokasi Indones., vol. 4, no. 1, 2016.

[14] P. Xue, Z. Wang, R. Zhang, Y. Wang, and S. Liu, "Highly efficient measurement technology based on hyper-spectropolarimetric imaging," Zhongguo Jiguang/Chinese J. Lasers, vol. 43, no. 8, pp. 107128,2016

[15] Haiyang Chen and Ronald P. Volpe, 1998, An Analysis of Personal Financial Literacy Among College Students, Financial Services Review, 7(2): 107-128.

[16] Ghozali, Imam, 2011, Aplikasi Analisis Multivariate Dengan Program IBM SPSS 23, Universitas Diponegoro, Edisi 7, Semarang.

[17] R.J.C Yap, F. Komalasari, I. Hadiansah, 2016, The Effect Of Financial Literacy And Attitude On Financial Management Behavior And Satisfaction, International Journal Of Administrative Science \& Organization isnis \& Birokrasi, Jurnal Ilmu Administrasi dan Organisasi, Volume 23, Number 3. 